\title{
Impaired specific CD8 T cell response with aging is not due to decreased expression of CD90 on TCR transgenic T cells
}

\author{
Jiu Jiang ${ }^{*}$, Erin Fisher and Donna M Murasko*
}

\begin{abstract}
Background: CD90 (Thy-1) is a small glycoprotein that is particularly abundant on the surface of mouse thymocytes and peripheral T cells, and is often used as a marker in adoptive transfer experiments to distinguish donor and recipient T cells with different CD90 subtypes. We have performed adoptive transfer experiments with $T$ cell receptor transgenic (TCR Tg) mice to study the impaired CD8 T cell response with aging.

Findings: After stimulation with a CD8 T cell epitope, $\mathrm{HA}_{518-524}$, the response of TCR Tg CD8 T cells from aged mice was decreased compared to the response of TCR Tg T cells from young mice. CD90 expression was also substantially decreased on the TCR Tg CD8 T cells of aged mice. However, the responses of CD90hi and CD90 low CD8 T cells of the aged mice were similar in both early activation and proliferation, demonstrating that the impaired $\mathrm{Tg} T$ cell response with aging is not associated with the altered CD90 expression on CD8 T cells.

Conclusions: The impaired Tg CD8 T cell response in aged mice is not due to age-associated changes in CD90 expression on Tg CD8 T cells.
\end{abstract}

Keywords: CD90, Transgenic, T cells, Aged mice

\section{Findings}

A decrease in the CD8 $\mathrm{T}$ cell response to virus infection with aging has been consistently observed [1-3], however, the mechanisms are still largely unknown. Both intrinsic and extrinsic factors are considered to affect the CD8 $\mathrm{T}$ cell response with aging $[4,5]$. The development of new immunological techniques, including $\mathrm{T}$ cell receptor transgenic (TCR Tg) mice [6-8], specific MHC tetramer staining [9], and lymphocyte sorting with flow cytometry, have significantly accelerated research concerning $\mathrm{T}$ cell immunity with aging $[2,3,10]$. Using an adoptive transfer approach, we observed that the aged environment significantly inhibits both clonal expansion and IFN- $\gamma$ production by specific Tg CD8 $\mathrm{T}$ cells of young mice during virus infection [3], and that the decreased response of the Tg CD8 T cells transferred into aged mice could be significantly enhanced when DCs of young mice were co-transferred [11]. These results

\footnotetext{
* Correspondence: jiu.jiang@drexel.edu; donna.murasko@drexel.edu Department of Biology, Drexel University, 3245 Chestnut Street, Philadelphia, PA 19104, USA
}

\section{() Biomed Central

(c) 2013 Jiang et al.; licensee BioMed Central Ltd. This is an Open Access article distributed under the terms of the Creative Commons Attribution License (http://creativecommons.org/licenses/by/2.0), which permits unrestricted use, distribution, and reproduction in any medium, provided the original work is properly cited. indicate that alterations in the aged environment play an important role in the decreased specific CD8 T cell immunity to virus infection with aging.

While the impairment of the aged environment affects the $\mathrm{T}$ cell response with aging, the intrinsic changes of $\mathrm{T}$ cells also play a critical role $[5,12,13]$. Since the percentage of specific CD8 T cells in wt mice is very low [14], we chose a TCR-Tg mouse model (i.e., Thy $-1.1^{+}$Clone- 4 , which recognizes $\mathrm{H}-2 \mathrm{~K}^{\mathrm{d}}$ hemagglutinin $(\mathrm{HA})_{518-526} \mathrm{CD} 8$ T cell epitope of influenza virus [8]) to examine whether aging has an effect on the intrinsic response of CD8 T cells. Although aged Clone-4 mice are not commercially available, we aged the mice in our animal facility.

Carboxyfluorescein succinimidyl ester (CFSE)-labeled splenocytes of young (2-3 month old) and aged (18-20 month old) Clone-4 mice were cultured with HA epitope. At different times post-stimulation (Days 1, 2, and $3)$, the proliferation of specific CD8 T cells was determined by flow cytometry based on the profile of CFSE, which is a vital fluorescent dye that is equally partitioned into daughter cells, allowing visualization of cell division [15]. The intensity, measured by mean fluorescence 
intensity (MFI) of CFSE, in cells continues to decrease as proliferation progresses. As shown in Figure 1A, little proliferation was observed in the CD8 $\mathrm{T}$ cells of either young or aged mice on Day 1. By Day 2, there was proliferation of both young and aged $\mathrm{T}$ cells, with a greater percentage of the $\mathrm{Tg} \mathrm{T}$ cells of young mice demonstrating proliferation (young vs aged: $97 \%$ vs $66 \%$ ). By Day 3 , most of the $\mathrm{T}$ cells of both young and aged mice had proliferated (young vs aged: 99\% vs 98\%); however, more proliferation of the $\mathrm{T}$ cells of young compared to aged mice was observed based on lower MFI of CFSE (MFI: Young vs aged: 18 vs 72; Figure 1A \& 1B). These data demonstrate that the response of specific CD8 T cells of Clone-4 mice is both delayed and decreased with aging, similar to the response in wt mice infected with influenza virus $[1,3]$.

CD90 (Thy-1), including subtypes Thy-1.1 and Thy-1. 2 , is a small glycoprotein that is particularly abundant on the surface of mouse thymocytes and peripheral $\mathrm{T}$ cells $[16,17]$. The CD90 molecule is often used in adoptive transfer experiments to distinguish donor and recipient $T$ cells with different CD90 subtypes [13,18]. Since our previous adoptive transfer of Clone-4 Tg CD8 $\mathrm{T}$ cells from young mice (Thy-1.1) into aged recipients (Thy-1.2) utilized the Thy marker to differentiate donor and recipient CD8 T cells [3], anti-Thy-1.1 is a standard antibody in our assessment of $\mathrm{Tg} \mathrm{T}$ cells. To our surprise, CD90 expression on the CD8 T cells of the aged Clone-4 mice was substantially decreased (Figure 2A, top panel) compared to young Clone-4 mice. In contrast, the ability of $\mathrm{Tg} \mathrm{T}$ cells of young and aged Clone- 4 mice to bind HA tetramer was similar (Figure 2A, lower panel). CD90 has been reported to play a role in murine
$\mathrm{T}$ cell activation since crosslinking CD90 molecules in the membrane raft results in the potent costimulation of $\mathrm{T}$ cells activated through the TCR [17]. Inhibition of $\mathrm{T}$ cell activation through down-regulation of TCR-CD3 expression can be mediated by an anti-CD 90 antibody [19]. Furthermore, Thy-1 signaling promotes the in vitro generation of CTLs that kill target cells in a granuledependent fashion [20]. To examine whether or not this age-associated change of CD90 expression contributes to the decreased $\mathrm{T}$ cell response with aging, we compared the responses of $\mathrm{CD} 90^{\mathrm{hi}}$ and $\mathrm{CD} 90^{\text {low }} \mathrm{CD} 8 \mathrm{~T}$ cells of aged Tg mice. On Days 1-3 post-stimulation with HA peptide, the proliferation (CFSE profile) and early activation (upregulation of activation markers, CD69 and CD25) of the two populations were similar (Figure 2B). We also compared the expression of CD44 on transgenic CD8 T cells of young and aged mice. While the cells of young and aged mice displayed the expected difference in CD44 expression with cells of aged mice demonstrating higher expression (data not shown), there was no difference in $\mathrm{CD} 44$ expression between $\mathrm{CD} 90^{\mathrm{hi}}$ and $\mathrm{CD} 90^{\text {low }} \mathrm{CD} 8 \mathrm{~T}$ cells of young or aged mice (Figure 3). After stimulation, the percentage of CD8 T cells demonstrating high levels of CD44 expression increased in both groups of mice (e.g., 24 h: Young: $56.5 \%$ to $84.8 \%$, Aged: $73.8 \%$ to $86.6 \%$ ). While the percentage of $\mathrm{CD} 0^{+} \mathrm{CD} 8 \mathrm{~T}$ cells did not change with in viro stimulation (data not shown), the expression of CD90 on the CD8 T cells of both young and aged mice was increased as indicated with MFI (Figure 4A). Interestingly, while there was no difference in CD44 expression of $\mathrm{CD} 90^{\text {low }}$ and $\mathrm{CD} 90^{\text {hi }}$ cells in aged mice, CD90 ${ }^{\text {hi }}$ cells of young demonstrated higher CD44 expression than CD90 ${ }^{\text {low }}$ cells (Figure 4B).
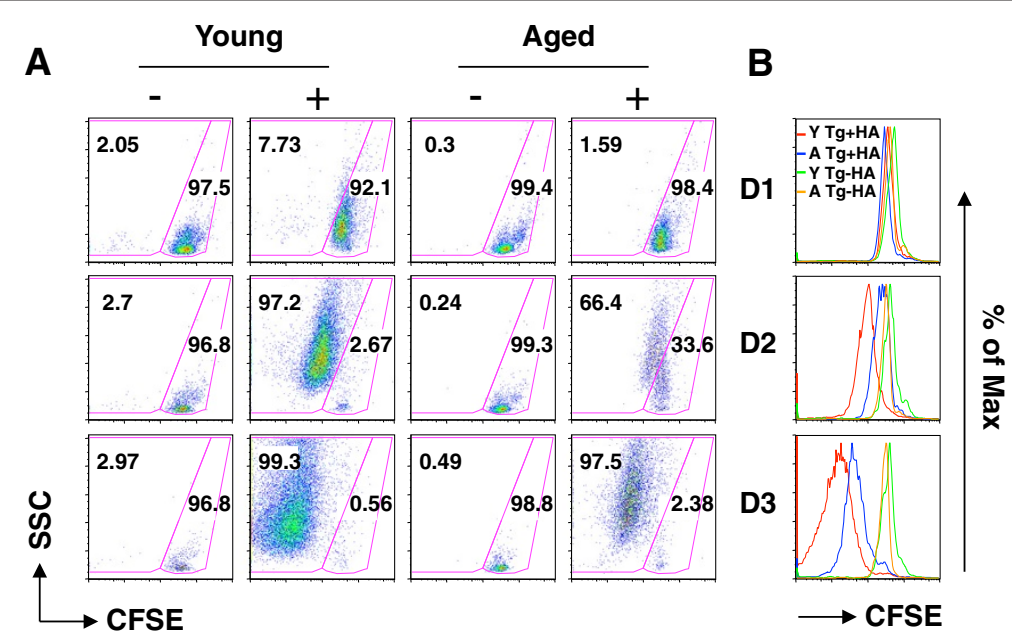

Figure 1 Decreased response of $\mathrm{T}$ cells from aged Clone-4 mice after stimulation with $\mathrm{HA}_{518-524} \cdot 1 \times 10^{5}$ CFSE labeled splenocytes of young and aged Clone-4 mice (Thy-1.1 ${ }^{+}$) were stimulated with or without $0.1 \mu \mathrm{M} \mathrm{HA}_{518-524}$ (+ or -). On Days 1, 2, and 3, cells were stained with anti-CD8 antibody. (A). Each flow cytometric plot shows proliferation of CD8 T cells based on the loss of CFSE. (B). Overlay of CFSE profiles of CD8 T cells from young and aged Clone-4 mice. Results are representative of three independent experiments with similar results. 


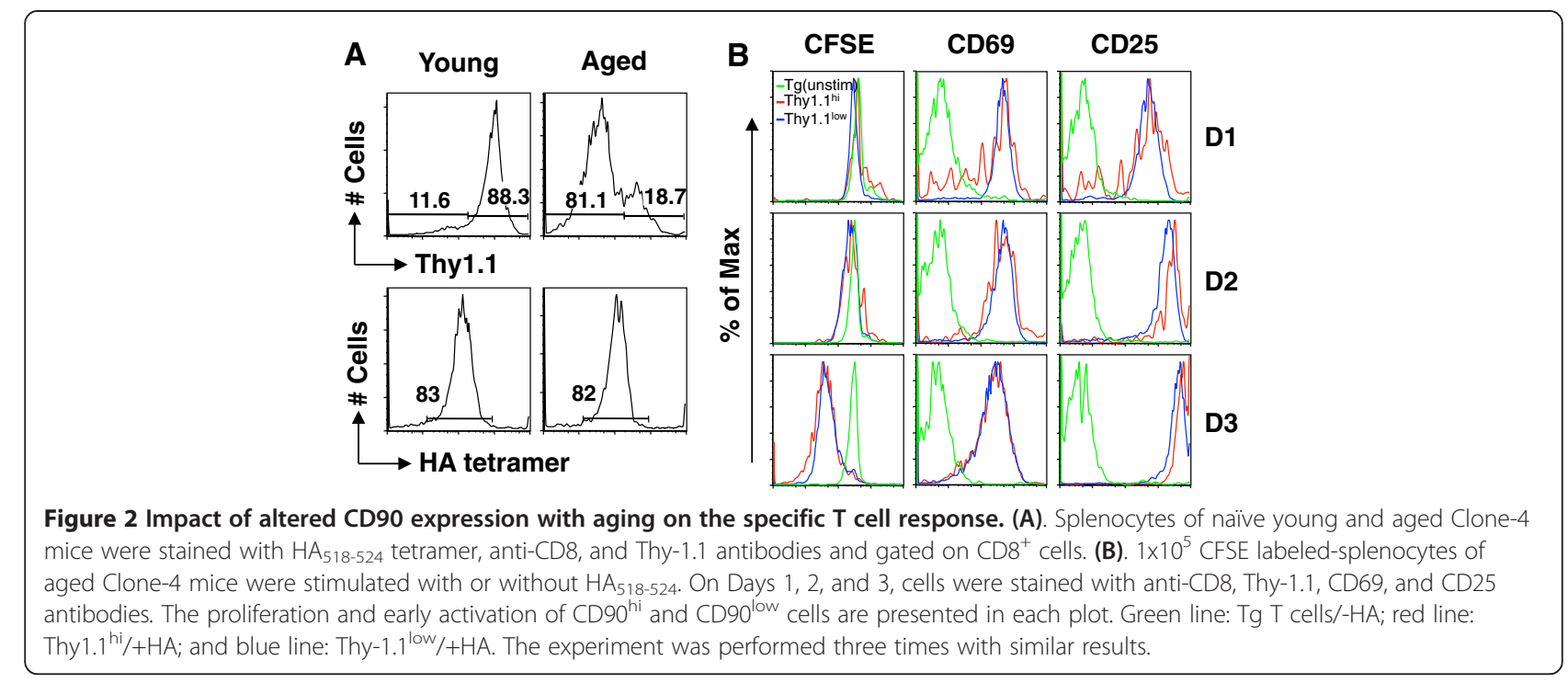

These results demonstrate that the age-associated changes in CD90 expression on Tg CD8 T cells do not contribute to the decreased $\mathrm{T}$ cell response with aging. It is also important when utilizing Thy-1 as a marker for donor cells in adoptive transfer experiments to be aware of a possible decrease of the glycoprotein on CD8 T cells of aged mice.

In summary, our findings demonstrate that: 1) CD90 expression on $\mathrm{Tg} \mathrm{CD} 8 \mathrm{~T}$ cells is diminished in aged mice, and 2) the impaired Tg CD8 $\mathrm{T}$ cell response of aged mice is not due to the age-associated changes in CD90 expression on Tg CD8 T cells. While it is known

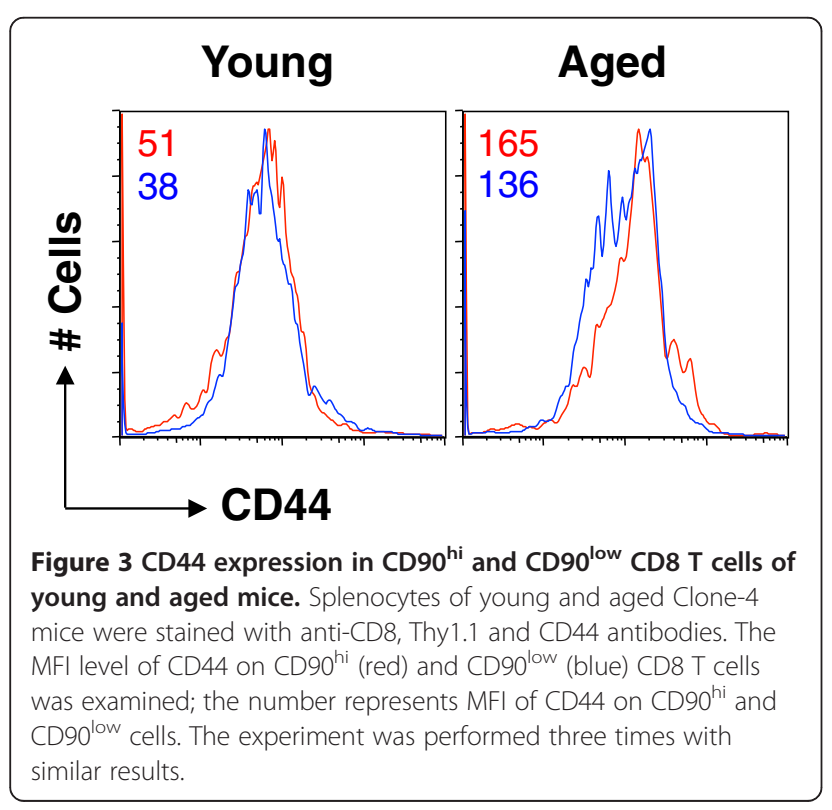

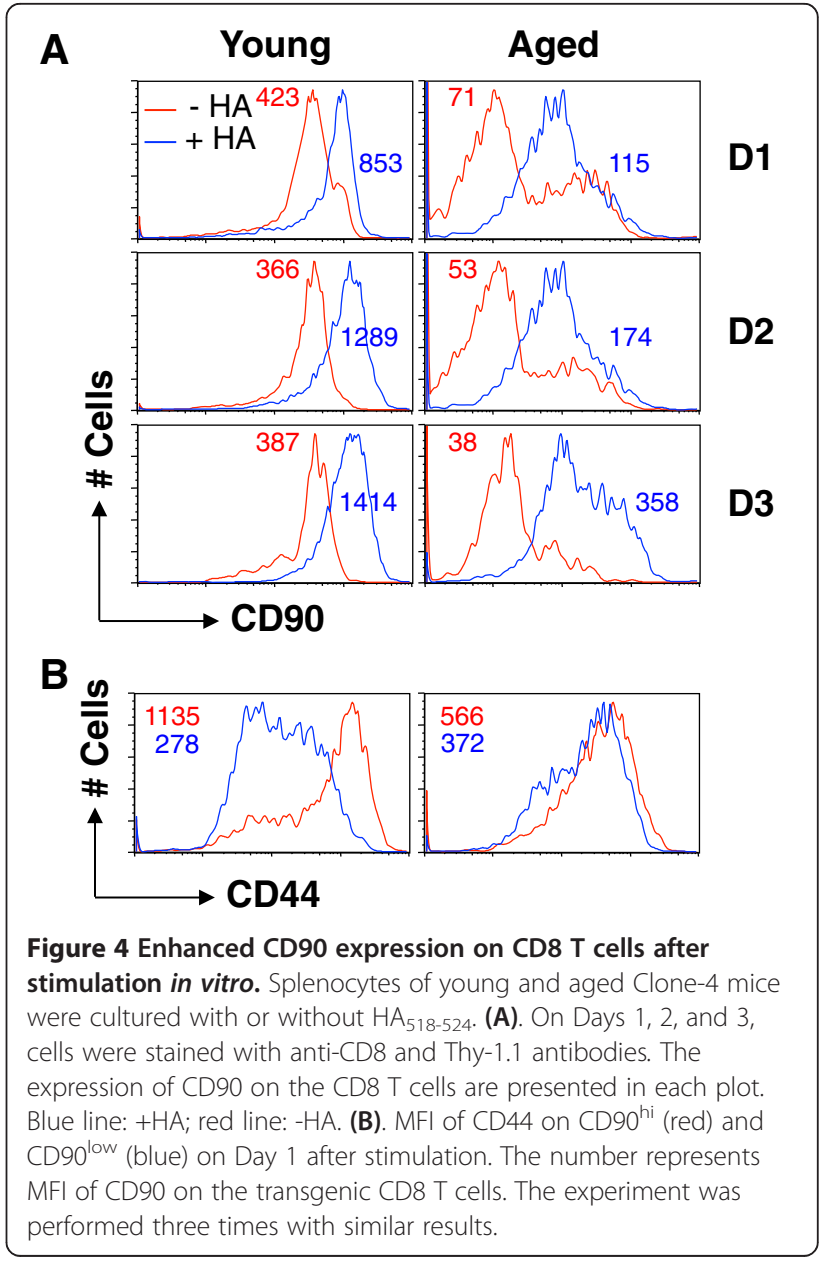


that both intrinsic and extrinsic factors contribute to the decreased $\mathrm{Tg} \mathrm{T}$ cell response with aging and the specific mechanisms are still under investigation, our data indicate that the age-associated change in CD90 on T cells is not a major indicator or contributor to the age-associated decrease in antigen-induced $\mathrm{T}$ cell proliferation.

\section{Abbreviations}

TCR: T cell receptor; CFSE: Carboxyfluorescein succinimidyl ester;

Tg: Transgenic; HA: Hemagglutinin; MFI: Mean fluorescence intensity.

\section{Competing interests}

The authors declare that they have no competing interests.

\section{Authors' contributions}

$J J$ and DMM designed and planned the research, and wrote the manuscript. $\mathrm{JJ}$ and EF performed experiments and analyzed data. All authors read and approved the final manuscript.

\section{Acknowledgments}

This work was supported by National Institutes of Health Grant AG14913. We thank MHC Tetramer Core Facilities of $\mathrm{NIH}$ at Atlanta for kindly providing $\mathrm{H}$ $2 \mathrm{~K}^{\mathrm{d}} \mathrm{HA}_{518-526}$ tetramer

Received: 20 March 2013 Accepted: 16 August 2013

Published: 19 August 2013

\section{References}

1. Po JL, Gardner EM, Anaraki F, Katsikis PD, Murasko DM: Age-associated decrease in virus-specific CD8+ T lymphocytes during primary influenza infection. Mech Ageing Dev 2002, 123:1167-1181.

2. Kapasi ZF, Murali-Krishna K, McRae ML, Ahmed R: Defective generation but normal maintenance of memory T cells in old mice. Eur J Immunol 2002, 32:1567-1573.

3. Jiang J, Bennett AJ, Fisher E, Williams-Bey Y, Shen H, Murasko DM: Limited expansion of virus-specific CD8 T cells in the aged environment. Mech Ageing Dev 2009, 130:713-721.

4. Murasko DM, Jiang J: Response of aged mice to primary virus infections. Immunol Rev 2005, 205:285-296.

5. Linton PJ, Li SP, Zhang Y, Bautista B, Huynh Q, Trinh T: Intrinsic versus environmental influences on T-cell responses in aging. Immunol Rev 2005, 205:207-219.

6. Ashton-Rickardt PG, Bandeira A, Delaney JR, Van Kaer L, Pircher HP, Zinkernagel RM, Tonegawa S: Evidence for a differential avidity model of T cell selection in the thymus. Cell 1994, 76:651-663.

7. Kaye J, Hsu ML, Sauron ME, Jameson SC, Gascoigne NR, Hedrick SM: Selective development of CD4+ T cells in transgenic mice expressing a class II MHC-restricted antigen receptor. Nature 1989, 341:746-749.

8. Kreuwel HT, Biggs JA, Pilip IM, Pamer EG, Lo D, Sherman LA: Defective CD8 + T cell peripheral tolerance in nonobese diabetic mice. J Immunol 2001, 167:1112-1117.

9. Altman JD, Moss PA, Goulder PJ, Barouch DH, McHeyzer-Williams MG, Bell لـ McMichael AJ, Davis MM: Phenotypic analysis of antigen-specific T lymphocytes. Science 1996, 274:94-96.

10. Haynes L, Linton PJ, Swain SL: Age-related changes in CD4 T cells of T cell receptor transgenic mice. Mech Ageing Dev 1997, 93:95-105.

11. Jiang J, Fisher E, Bennett AJ, Murasko DM: Enhancement of virus-specific expansion of transgenic CD8 T cells in aged mice by dendritic cells. Mech Ageing Dev 2010, 131:580-583.

12. Miller RA, Berger SB, Burke DT, Galecki A, Garcia GG, Harper JM, Sadighi Akha AA: T cells in aging mice: genetic, developmental, and biochemical analyses. Immunol Rev 2005, 205:94-103.

13. Jiang J, Gross D, Elbaum P, Murasko DM: Aging affects initiation and continuation of T cell proliferation. Mech Ageing Dev 2007, 128:332-339.

14. Obar JJ, Khanna KM, Lefrancois L: Endogenous naive CD8+ T cell precursor frequency regulates primary and memory responses to infection. Immunity 2008, 28:859-869.

15. Lyons $A B$ : Analysing cell division in vivo and in vitro using flow cytometric measurement of CFSE dye dilution. J Immunol Methods 2000, 243:147-154.
16. Pont S: Thy-1: a lymphoid cell subset marker capable of delivering an activation signal to mouse T lymphocytes. Biochimie 1987, 69:315-320.

17. Haeryfar SM, Hoskin DW: Thy-1: more than a mouse pan-T cell marker. J Immunol 2004, 173:3581-3588.

18. Badovinac VP, Haring JS, Harty JT: Initial T cell receptor transgenic cell precursor frequency dictates critical aspects of the CD8(+) T cell response to infection. Immunity 2007, 26:827-841.

19. Nishida E, Chen C, Morita A, Shimizu J: Inhibition of T cell activation through down-regulation of TCR-CD3 expression mediated by an antiCD90 Ab. Immunol Lett 2011, 136:163-170.

20. Haeryfar SM, Conrad DM, Musgrave B, Hoskin DW: Antibody blockade of Thy-1 (CD90) impairs mouse cytotoxic T lymphocyte induction by antiCD3 monoclonal antibody. Immunol Cell Biol 2005, 83:352-363.

doi:10.1186/1742-4933-10-36

Cite this article as: Jiang et al: Impaired specific CD8 T cell response with aging is not due to decreased expression of CD90 on TCR transgenic T cells. Immunity \& Ageing 2013 10:36.

\section{Submit your next manuscript to BioMed Central and take full advantage of:}

- Convenient online submission

- Thorough peer review

- No space constraints or color figure charges

- Immediate publication on acceptance

- Inclusion in PubMed, CAS, Scopus and Google Scholar

- Research which is freely available for redistribution 